\title{
Weichselian sedimentary record and ice-flow patterns in the Sodankylä area, central Finnish Lapland
}

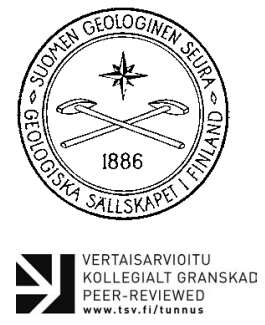

KOLLEGIALT GRAN
PEER-REVIEWED
www. IS.

\author{
Annika Katarina Åberg ${ }^{i *}$, Seija Kultti ${ }^{\mathrm{I}}$, Anu Kaakinen ${ }^{\mathrm{I}}$, \\ Kari O. Eskola ${ }^{2}$ and Veli-Pekka Salonen ${ }^{\mathrm{I}}$ \\ ${ }^{1}$ Department of Geosciences and Geography, University of Helsinki, P.O. Box 64, \\ Gustaf Hällströmin katu 2b, FI-00014 Helsinki, Finland \\ ${ }^{2}$ Laboratory of Chronology, Finnish Museum of Natural History, P.O. Box 64, \\ Gustaf Hällströmin katu 2b, FI-00014 Helsinki, Finland
}

\begin{abstract}
Three different till units separated by interstadial fluvial deposits were observed in the Sodankylä area in the River Kitinen valley, northern Finland. The interbedded glaciofluvial sediments and palaeosol were dated by OSL to the Early $(79 \pm 12$ to $67 \pm 13 \mathrm{ka})$ and Middle (41 $\pm 9 \mathrm{ka})$ Weichselian. A LiDAR DEM, glacial lineations, the flow direction of till fabrics, esker chains and striations were applied to investigate the glacial flow patterns of the Sodankylä, Kittilä and Salla areas. The analysis revealed that the youngest movement of the Scandinavian Ice Sheet is not visible as DEM lineations within the studied areas. The modern morphology in Kittilä and Salla shows streamlined landforms of various dimensions mainly oriented from the NW and NNW, respectively, corresponding to the Early/Middle Weichselian ice-flow directions inferred from till fabrics. The Late Weichselian ice flow has produced an insignificant imprint on the landforms. This study suggests a northern location for the ice-divide zone during the Early/Middle Weichselian, and a more western-southwestern position during the Late Weichselian. The OSL ages of $14 \pm 3.3 \mathrm{ka}$ from the aeolian deposits may indicate ice-free areas during the Bølling-Allerod warm period in the vicinity of the River Kitinen.
\end{abstract}

Keywords: Quaternary, till stratigraphy, LiDAR DEM, glacial lineations, weak glacial erosion, interstadial deposits, OSL

* Corresponding author (email: annika.aberg@helsinki.fi)

Editorial handling: Niina Kuosmanen (e-mail: kuosmanen.niina@gmail.com) 


\section{Introduction}

The Weichselian depositional history of Lapland is a result of the unusual preservation of strata from consecutive glacial and non-glacial climate events, thus offering a unique, still inadequately known window on the climate history of the core area occupied by the Scandinavian Ice Sheet (SIS). The frequent occurrence of Neogene weathering crust (saprolith) and preservation of pre-Late Weichselian tills with interbedded sorted sediments and organic remains, as well as erosion remnants such as tors (Fig. 1), indicate repeatedly weak glacial erosion during the Quaternary as a result of prevailing frozen bed conditions during glaciations (Kujansuu, 1967; Kleman et al., 1997; Johansson \& Kujansuu, 2005; Kleman \& Glasser, 2007; Ebert et al., 2015).

It has been proposed that up to five glacier advances and related till units are recorded in Finnish Lapland (Johansson et al., 2011). In western Lapland (Rautuvaara and Hannukainen), there is evidence of two Middle Weichselian and one Early Weichselian stadial and associated ice-free events (Salonen et al., 2014, Howett et al., 2015, Lunkka et al., 2015). In eastern Lapland, a recent stratigraphic scheme from Sokli indicates three glacial events during the Weichselian (Helmens, 2014), one of which has been correlated with the



Figure 1. Index map showing the study area and three LiDAR image analysis areas in central Finnish Lapland. Administrative borders of Finland and hill-shaded DEM 32 m: (c modified and reproduced after the National Land Survey of Finland, 2016. Administrative borders of Norway, Russia and Sweden: www.gadm.org (visited 4/2017). 
Middle Weichselian (Savukoski III, MIS 4). These stratigraphic studies have been accompanied by several age determinations, e.g. in Sokli (Helmens et al.; 2000; 2007a; 2007b; 2018; Helmens, 2014), Tervola (Mäkinen, 2005), Rautuvaara (Howett et al., 2015; Lunkka et al., 2015), Hannukainen (Salonen et al., 2014), Kittilä (Sarala \& Eskola, 2011), Sodankylä (Sarala et al., 2015) and Inari (Sarala et al., 2016).

The central Lapland region represents the core area of weak glacial erosion with many deposits predating the Late Weichselian (Hirvas, 1991; Aalto et al., 1992; Salonen et al., 2014; Howett et al.; 2015; Lunkka, et al. 2015; Sarala et al., 2015; Åberg et al., 2017). The Sodankylä area is characterized by an open landscape consisting of large mire complexes and a series of river systems, the latter of which are presumed to be of preglacial origin (Johansson \& Kujansuu, 2005). There are also a few important stratigraphic sites such as Paloseljänoja (Hirvas, 1991) and representative stratigraphic reference sites such as the extensive till sections studied in Kevitsa (Hirvas et al., 1994). Moreover, the region has recently been remapped for its Quaternary deposits (Sarala et al., 2015) and a comprehensive 3D database exists on surficial geology over the Kersilö area in Sodankylä (Åberg et al., 2017). Despite the several accounts concerning the Quaternary geology of the Sodankylä area and central Lapland in general, central Lapland has only a few age determinations as well as sedimentary records from the Middle Weichselian (MIS 3, 4) deposits (Putkinen et al., 2020).

This paper presents new sedimentological and lithological observations, LiDAR image analyses and OSL age determinations from three areas within the so-called ice-divide zone (Hirvas et al., 1977; Hirvas, 1991) in the River Kitinen valley in Kärväsniemi, Sodankylä, which in an earlier 3D model study (Åberg et al., 2017) was shown to contain a variable succession of glacial and fluvial sediments, and hypothesised to also include Middle Weichselian deposits. The aims of the current study were to 1) describe the sedimentary successions and interpret the depositional environments, 2) reconstruct the glacial history of central Finnish Lapland and, finally, 3) synthesize the Weichselian ice-flow patterns in Finnish Lapland.

\section{Study area}

Our study area lies in the municipality of Sodankylä near Kersilö village in the River Kitinen valley, northern Finland (Fig. 2). Overall, the study area is a flat peneplain (180-200 m above sea level) covered by sands or mire lowlands (Fig. 1). Occasional morainic terrains and bedrock hills break through the generally even topography (Räisänen, 2014; Sarala et al., 2015).

The local bedrock is part of the Central Lapland Greenstone belt and consists of mafic volcanic rocks, graphite paraschists, quartzite and gabbro (Tyrväinen, 1983; Hanski \& Huhma, 2005). The altitude of the bedrock surface varies from 150 $190 \mathrm{~m}$ a.s.l. The unconsolidated Pleistocene and Holocene deposits in Sahankangas/Kärväsniemi attain a thickness of $10-30 \mathrm{~m}$ and they have accumulated in a valley-form basin of bedrock (170-150 m a.s.l. Åberg et al., 2017) possibly eroded by pre-Quaternary rivers.

The present investigations of the Quaternary sedimentary successions were undertaken in three areas: Sahankangas (Kärväsniemi KN-1 and KN-2 and Hietakangas), Kuusivaara and Multaharju (Fig. 2). The main site, Sahankangas, is located along the River Kitinen about $15 \mathrm{~km}$ NNE of the centre of the municipality of Sodankylä, between the villages of Sattanen and Kersilö (Fig. 2). Sahankangas has been interpreted by Räisänen (2014) as a sand-covered outwash plain with underlying basal till. A hillshade generated from a LiDARderived 2-metre digital elevation model (DEM) shows a braided river pattern in Sahankangas and Pahanlaaksonmaa. The sandur plains are deposited at the levels of $188 \mathrm{~m}$ a.s.l. and $185 \mathrm{~m}$ a.s.l. The present morphology of Sahankangas reflects the past and present activity of the River Kitinen 


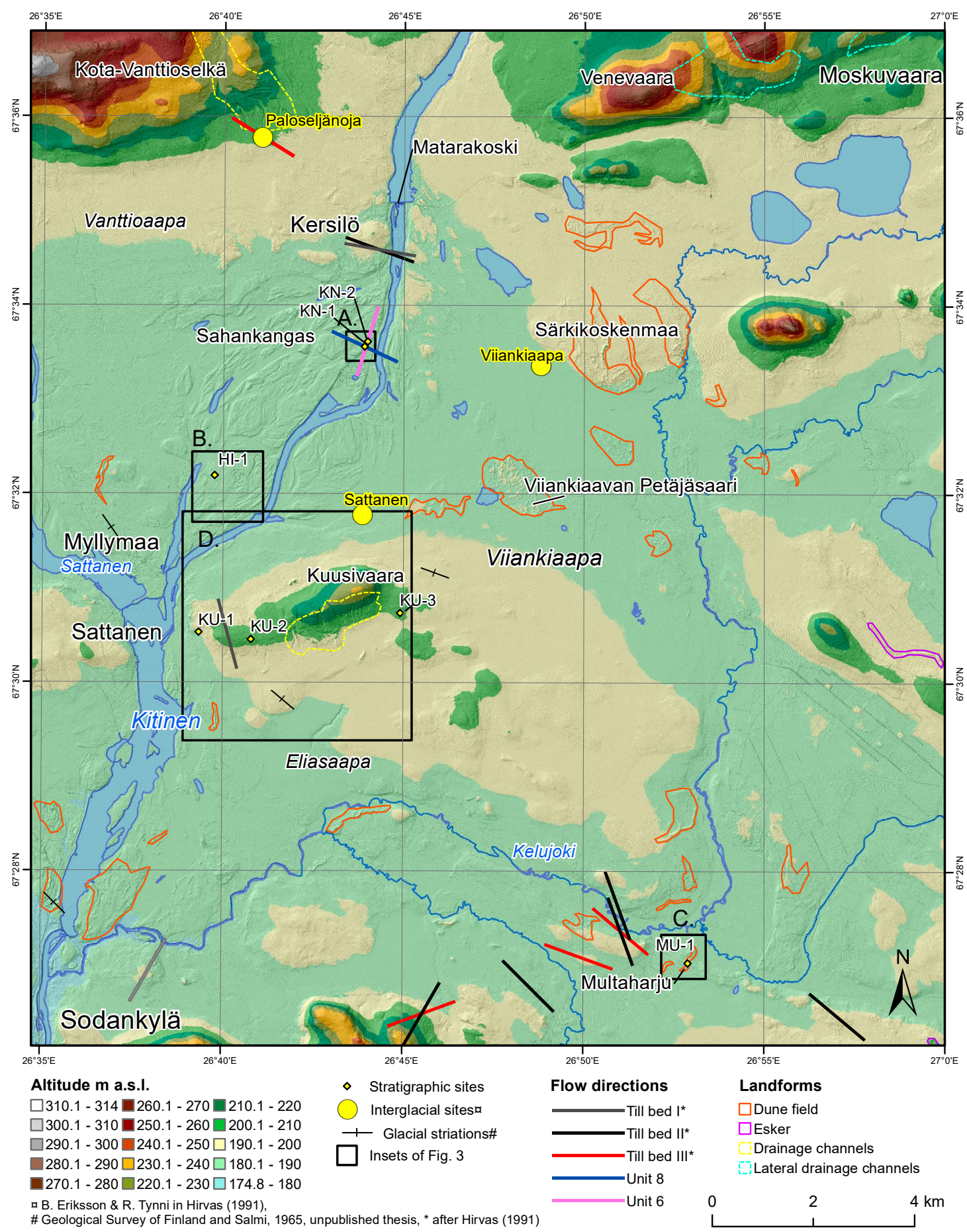

Figure 2. The locations of the studied sections in Kärväsniemi (KN-1 and 2), Hietakangas (HI-1), Multaharju (MU-1) and Kuusivaara (KU1-3) in Sodankylä, central Finnish Lapland. Unit 6 and Unit 8 refer to the units in this study. LiDAR DEM (2 m):@ modified and reproduced after the National Land Survey of Finland, 2019. Water bodies are modified after U43, U44, U51 and U52 (Topographic map 1:100 000), National Land Survey of Finland, 2016. Rivers are modified and reproduced after water bodies of the EU Water Framework Directive, Finnish Environment Institute, 2014. 
Table 1. Locations of the studied sedimentary successions in Sodankylä, central Finnish Lapland.

\begin{tabular}{llll}
\hline Name, site & Coordinates & Top (ma.s.I.) & Thickness $(\mathrm{m})$ \\
\hline KN-1, Kärväsniemi & $67^{\circ} 33.569^{\prime} \mathrm{N}, 26^{\circ} 43,915^{\prime} \mathrm{E}$ & 186.6 & 5.6 \\
KN-2, Kärväsniemi & $67^{\circ} 33.620^{\prime} \mathrm{N}, 6^{\circ} 43.992^{\prime} \mathrm{E}$ & 188.0 & 6.3 \\
HI-1, Hietakangas & $67^{\circ} 32.197^{\prime} \mathrm{N}, 26^{\circ} 39.762^{\prime} \mathrm{E}$ & 183.0 & 1.0 \\
KU-1, Kuusivaara & $67^{\circ} 30,460^{\prime} \mathrm{N}, 26^{\circ} 39,429^{\prime} \mathrm{E}$ & 190.0 & 2.7 \\
KU-2, Kuusivaara & $67^{\circ} 30,437^{\prime} \mathrm{N}, 26^{\circ} 40,231^{\prime} \mathrm{E}$ & 203.5 & 2.1 \\
KU-3, Kuusivaara & $67^{\circ} 30,662^{\prime} \mathrm{N}, 26^{\circ} 45,196^{\prime} \mathrm{E}$ & 201.0 & 3.0 \\
MU-1, Multaharju & $67^{\circ} 27.039^{\prime} \mathrm{N}, 26^{\circ} 52.897^{\prime} \mathrm{E}$ & 188.0 & 1.6 \\
\hline
\end{tabular}

from the time when it drained from the Muonio and Porttipahta ice lakes to the Moskuvaara Ice Lake about 10500 years ago, during deglaciation (Johansson \& Kujansuu, 2005).

Kuusivaara hill is located ca. $1.5 \mathrm{~km} \mathrm{SE}$ of Sattanen village and lies on the eastern side of the River Kitinen. The top of Kuusivaara reaches an altitude of $230 \mathrm{~m}$ a.s.l. and the hill rises $35 \mathrm{~m}$ above its surroundings. Kuusivaara hill is covered by thin glacial deposits, mainly consisting of till (Räisänen, 2014). The third investigated area, Multaharju, is located near Siurumaa, $12 \mathrm{~km}$ ENE of Sodankylä centre. The sandy ridge of Multaharju has been interpreted as an aeolian sand dune by Räisänen (2014). It rises $2-3$ metres from its surroundings, reaching a level of $190 \mathrm{~m}$ a.s.l. on top. These dune ridges are a common morphological feature occupying sandy shores of the ancient Moskujärvi Ice Lake at altitudes of 180-200 m a.s.l. (Fig. 2).

\section{Material and methods}

\subsection{Sedimentological studies}

Altogether, seven outcrops in the three study areas were selected for detailed sedimentological investigations. Kärväsniemi is an eastern extension of the Sahankangas outwash plain and is a critical site for understanding the depositional history of the River Kitinen valley. Wide exposures with interbedded sand and diamicton units were accessible in a gravel pit in Kärväsniemi, where two sections (KN-1 and $\mathrm{KN}-2)$ were examined. Additional vertical profiles with OSL age determinations were generated from neighbouring shallow sand pits in Hietakangas (HI-1) and Multaharju (MU-1), which are of importance in understanding the deglaciation in the area. Kuusivaara (KU-1, KU-2 and KU-3) was investigated in order to examine glacial deposits located at higher elevations compared to the River Kitinen valley fluvial deposits (cf. Räisänen, 2014). The locations of the sections are indicated in Fig. 1, with additional information provided in Table 1 .

The sections were studied for their sedimentological properties, including lithology, unit dimensions and boundaries, their lateral and vertical variation and continuity, as well as sedimentary and deformation structures. Samples were collected for granulometric analysis (22 samples) and OSL age determinations (6 samples) (Table 2$)$. Till fabric was measured from five diamicton units based on an average of 50 clasts. The lithofacies classification used was modified from Eyles et al. (1983).

\subsection{OSL age determinations}

Seven samples for optical dating were collected from the sites using $\varnothing 5$-cm PVC tubes driven directly into freshly cleaned pit faces. The sampled units represented well-sorted medium to fine sands in shallow channel fills, aeolian dunes and palaeosols (Table 2). Sample preparation and OSL measure- 
Table 2. OSL age determinations of the studied sections in Hietakangas, Multaharju, Kärväsniemi and Kuusivaara in Sodankylä, Finnish Lapland. See Table 1 for site locations.

\begin{tabular}{lllllll}
\hline Lab number & Site & Sample & Material & $\begin{array}{l}\text { Palaeodose } \\
(\text { Gy })\end{array}$ & Age (ka) & Total BGR (mGy/a) \\
\hline Hel-TL04301 & Hietakangas & HI-1a & Fluvial sand & $\begin{array}{l}26.1 \pm 3.18 \\
48.6 \pm 3.61\end{array}$ & $\begin{array}{l}11 \pm 2.0 \\
21 \pm 3.0\end{array}$ \\
Hel-TL04302 & Multaharju & MU-1 & Aeolian sand & $23.4 \pm 4.09$ & $14 \pm 3.2$ & $1.7 \pm 0.3$ \\
Hel-TL04344 & Kärväsniemi & KN-2-Unit 7 & Fluvial sand & $79.0 \pm 11.6$ & $41 \pm 9$ & $1.9 \pm 0.3$ \\
Hel-TL04300 & Kärväsniemi & KN-2-Unit5 & Sandy palaeosol & $128 \pm 16.8$ & $67 \pm 13$ & $1.9 \pm 0.2$ \\
Hel-TL04299 & Kärväsniemi & KN-2-Unit 4 & Fluvial sandy gravel & $133 \pm 16.2$ & $75 \pm 15$ & $1.8 \pm 0.3$ \\
Hel-TL04298 & Kärväsniemi & KN-1-Unit 4b & Fluvial sand & $155 \pm 6.97$ & $79 \pm 12$ & $2.0 \pm 0.2$ \\
Hel-TL04340 & Kuusivaara & KU-3-Unit 3 & Sandy palaeosol & $138 \pm 14.7$ & $79 \pm 15$ & $1.8 \pm 0.3$ \\
\hline
\end{tabular}

ments were undertaken in the Laboratory of Chronology, Finnish Museum of Natural History, University of Helsinki.

Gamma Dose measurements for the OSL age determinations were recorded on-site in the field using a portable ICx-Identifinder gamma spectrometer with a $\varnothing 1.4 " \times 2 " \mathrm{NaI}(\mathrm{TI})$ detector. The gamma measurement also included cosmic radiation. The beta dose rate was determined in the laboratory using a Risø GM-25-5 beta multicounter (Bøtter-Jensen \& Mejdahl, 1988). The measured beta dose rate was converted to the absorbed dose based on the measurements of a set of samples with known $\mathrm{U}$, Th and $\mathrm{K}$ contents, as determined by neutron activation. The effects of the water content on the dose rates were calculated according to Aitken (1985). Originally, the sampled sections had been below the areal groundwater table, possibly during most of their existence. The analysis assumes water contents of Wsample $=$ Wsoil $=0.2$ (saturation water content 20\%) and fractional water uptake $\mathrm{F}=0.3 \pm 0.1$. This estimation is based on relatively dry conditions $(30 \pm 10 \%$ of the saturated water content).

The OSL measurements were carried out from quartz and performed with an upgraded Ris $\varnothing$ TL-DA-12 reader (Bøtter-Jensen \& Duller, 1992; Bøtter-Jensen et al., 1999). Sample preparation involved sieving to obtain the grain size of 210 $297 \mu \mathrm{m}$, density separation to extract the quartz, and etching with $\mathrm{HF} 40 \% / 1 \mathrm{~h}$ and $\mathrm{HCl} 10 \% / 30$ $\min$. The measurement routine was based on the single aliquot regeneration (SAR) protocol (Murray $\&$ Wintle, 2000).

\subsection{Flow direction analysis}

The examination of the Weichselian ice-flow directions and landforms in central Lapland was mainly based on the analysis of a 2-metre-resolution digital elevation model (DEM) generated from LiDAR (light detection and ranging) by the National Land Survey of Finland (available via the File service of open data [https://tiedostopalvelu. maanmittauslaitos.fi/tp/kartta?lang=en]) and a geological mapping dataset available via the Hakku service of the Geological Survey of Finland. The analyses were implemented in three areas: the neighbouring Salla and Kittilä lobes east and west of the study area (see Putkinen et al., 2017) and the Sodankylä interlobate complex between them.

For the three areas, each $1080 \mathrm{~km}^{2}$ in area, a hill-shaded digital elevation model (LiDAR DEM) was investigated. Altogether, 611 glacial lineations and eskers overlapping with the study areas were compiled from the glacial features database of GTK (available from the Hakku service [https:// hakku.gtk.fi/]). Furthermore, 130 new streamlined bedforms detected were digitized from the LiDAR DEMs using the ArcMap (ESRI) editing 
tool. Glacial lineations comprised a wide variety of streamlined bedforms and erosional features indicative of glacial flow directions, including drumlins or drumlinoids, flutings, megaflutings, overridden bedforms and undefined glacial lineations. Twenty glacial lineations from the glacial features database were rejected, since they were not detectable from the LiDAR DEM or represented bedrock forms (Electronic Appendix A). Transverse moraines and glaciofluvial landforms were also omitted. Eskers (likewise, coarse-grained esker cores and esker sands) were categorized into two classes, eskers and till-covered eskers, according to Sutinen (1992 and references therein), Johansson (1995) and Johansson \& Kujansuu (2005). For each esker, a flow direction was determined based on the longest axis of the esker polygon. More rounded shapes received an estimated flow direction. Two esker sand polygons were found to represent postglacial faults (Electronic Appendix B), and were thus rejected from the analysis.

A total of 110 till fabric measurements (see Electronic Appendix C and D) were compiled from the stratum data for the superficial deposits database of GTK (https://hakku.gtk.fi/) and six additional till fabric measurements (3 unpublished, comprising 2 from Kevitsa and 1 from Sukuvaara; 1 from Paloseljänoja, Hirvas (1991)) and till fabric from Units 8 and 6 (described below) from $\mathrm{KN}-1$ and $\mathrm{KN}-2$, respectively, were included in the analyses. The compiled till fabric data were classified as Late Weichselian and Early/Middle Weichselian; the topmost tills and till beds I and II of Hirvas (1991) were grouped as Late Weichselian, whereas the "lower tills" and bed III of Hirvas (1991) were assumed to correspond to the Early/Middle Weichselian. Till beds IV and V of Hirvas and the till fabrics with ambiguous stratigraphic positions were omitted from the analysis.

Eighteen striations falling within the study areas were compiled from the striations database of GTK (https://hakku.gtk.fi/) (Fig. 2) and included in the flow direction analysis together with three unpublished data points (Salmi 1965) and one from Tanner (1915) (Electronic Appendix E).

\section{Results}

\subsection{Lithofacies description of units and interpretation}

\subsubsection{Kärväsniemi sections}

Kärväsniemi is an eastern extension of the $\mathrm{Sa}$ hankangas outwash plain (Fig. 3) deposited at $188 \mathrm{~m}$ a.s.l. and excavated for the gravel (aggregate) resources. The section crosses through the outwash plain up to a length of $1 \mathrm{~km}$. Two sections were selected to study the sedimentological features of Kärväsniemi: KN-1 on the NW side of the gravel pit and KN-2 about $200 \mathrm{~m} \mathrm{NE}$ of KN-1 (Fig. 3). The section logs are presented in Fig. 4 with their proposed lithostratigraphical correlations, and they consisted of the following units:

The lowermost unit (Unit 1, Dmm) is found at both Kärväsniemi sites. It is comprised of well consolidated, massive silty diamicton with numerous abundant clasts up to boulder size. The lower boundary has not been revealed. The thickness of the unit is at least one metre and forms a continuous flooring in the Kärväsniemi area, extending for at least one kilometre. The groundwater table was observed at the top of Unit 1 in $\mathrm{KN}-1$.

Unit $2(\mathrm{Gm} / \mathrm{Sm})$ represents massive bimodal gravel and sand that crops out in both Kärväsniemi sections. Its thickness varies from $1.6 \mathrm{~m}$ in $\mathrm{KN}-1$ to $0.7 \mathrm{~m}$ in $\mathrm{KN}-2$. Towards the top of the unit in $\mathrm{KN}-2$, the sands display a bed coloured by iron oxides. The top part of the unit in $\mathrm{KN}-1$ is finer in grain size. The basal contact could not be detected due to the poor exposure of underlying Unit 1; in $\mathrm{KN}-2$, the contact was close to the groundwater table.

Upwards follows ca. $1 \mathrm{~m}$ of matrix-supported diamicton (Unit 3, Dms $(m)$ ), which has a gradational contact to the underlying Unit 2 . The sediment is texturally polymodal, ranging from fine sand to boulders with occasional lenses or beds of sand. Towards KN-2, the unit becomes slightly finer and better sorted, and is faintly stratified. Imbricate clusters of larger clasts dip gently eastwards. 


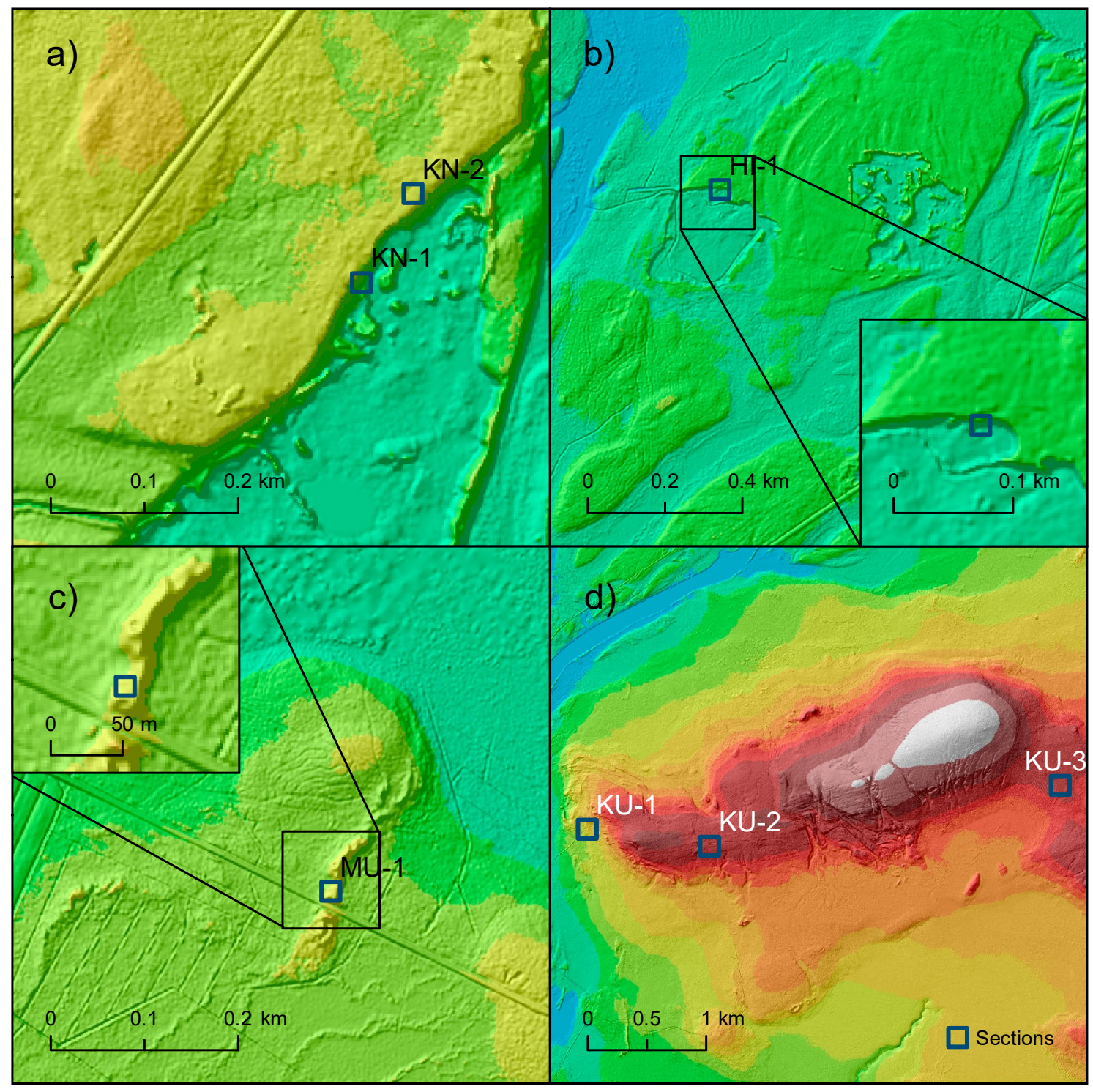

Altitude $\mathrm{m}$ a.s.I.

\begin{tabular}{|c|c|c|c|c|c|c|}
\hline $174-182$ & $184.1-186$ & $\mid 188.1-190$ & $192.1-194$ & $196.1-198$ & $200.1-205$ & $210.1-220$ \\
\hline $182.1-184$ & $186.1-188$ & $190.1-192$ & $194.1-196$ & $198.1-200$ & $205.1-210$ & $220.1-230.7$ \\
\hline
\end{tabular}

Figure 3. Hill-shaded LiDAR DEM figures indicating the locations of the studied sections in Sodankylä. A. Kärväsniemi. B. Hietakangas. C. Multaharju in Siurunmaa. D. Sections of Kuusivaara. LiDAR DEM: (C) modified and reproduced after the National Land Survey of Finland, 2019. 
KN-1 Kärväsniemi

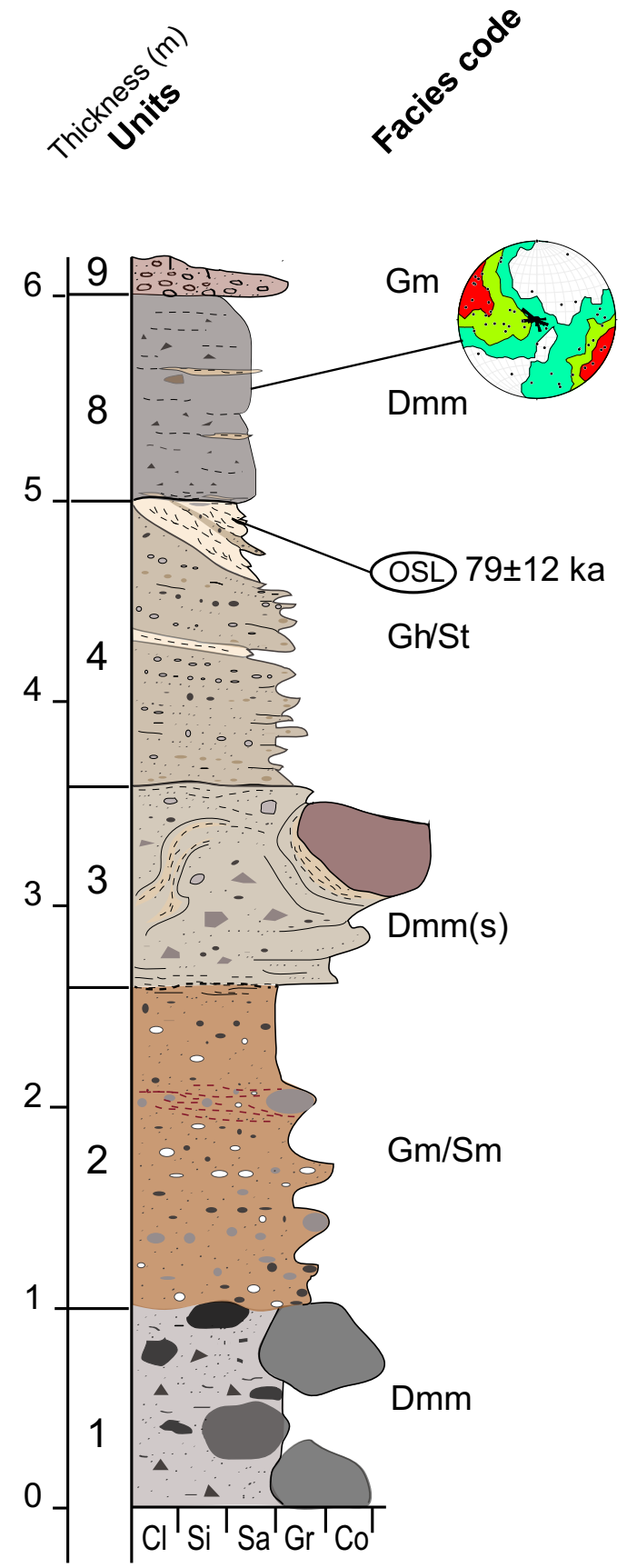

KN-2 Kärväsniemi
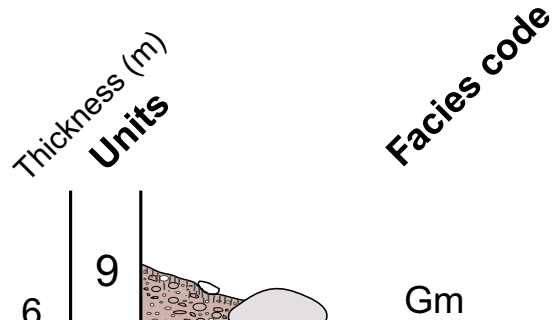

Dmm

Gh/Sh
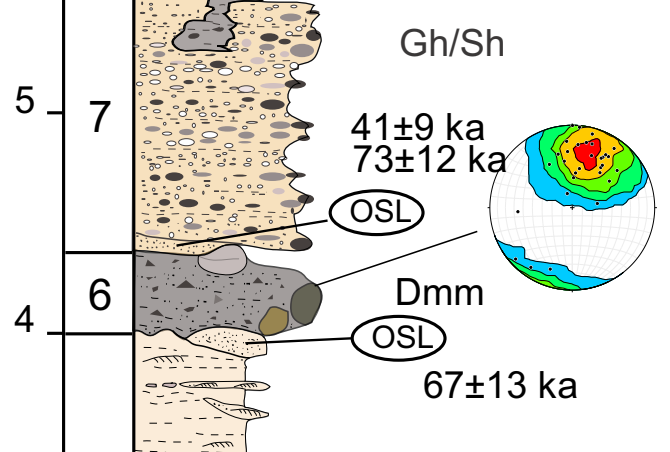

Sh/Sr, P

1

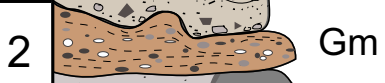

0

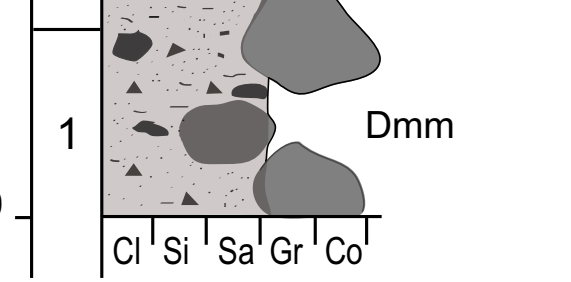

Figure 4. Kärväsniemi sedimentary logs KN-1 and KN-2, with fabric measurements and OSL age results marked. Location depicted in Figs. 2 and 3. 
Unit 4 (Gh, St, Sh), recognised at both Kärväsniemi sites, comprises alternating beds of wellsorted sand and gravel. The beds show variable thicknesses and grain sizes with sharp lower contacts. In $\mathrm{KN}-1$, the unit is $1.4 \mathrm{~m}$ thick and is dominated by gravel-sized grain sizes with cobblesized clasts showing weak imbrication. A solitary trough of cross-stratified sand exists in the upper part of the unit. This unit was sampled for OSL age determination from both sections (Hel-TL04299 and Hel-TL04298; Table 2).

Unit 5 (Sh, Sr, P), observed in KN-2 of Kärväsniemi, is $1.6 \mathrm{~m}$ thick and rests on the underlying sorted sands and gravels of Unit 4 with a sharp conformable lower contact. The unit comprises alternating thin beds of fine and medium sand of up to $3-5 \mathrm{~cm}$ in thickness; the thickness of individual beds follows an upwards-decreasing trend and textures grade vertically into fine sands and silts. In the lower part of the succession, individual beds display ripple cross-lamination and dropstones $(5-10 \mathrm{~cm})$ with loaded lower contacts. Within the upper level of the unit, 20-cm-thick remains of podsol soil are observed; the soil is penetrated by a ca. 50-cm-deep ice wedge cast. The pedon consists of an organic tint (10YR3/1) on the top, underlain by a light grey (10YR7/3) leaching horizon and reddish (10YR5/6) enrichment zone. An OSL sample (Hel-TL04300, Table 2) was obtained from the podsol horizon.

Unit $6(\mathrm{Dmm})$ is observed in $\mathrm{KN}-2$ of Kärväsniemi and comprises a $30-\mathrm{cm}$-thick diamicton that shows a lower sharp and erosive boundary. The diamicton bed has a silty-sandy matrix, is massive, matrix supported, and contains very angular clasts up to $10-20 \mathrm{~cm}$ in size. Fabric analysis indicated a preferred orientation of clasts, showing a northnortheastward dominating dip orientation. On the top of the unit, a boulder with a striated $\left(015^{\circ}\right)$ surface was observed.

Unit 7 (Gh, Sh), which is only observed in KN-2 of Kärväsniemi, is a 1.3-m-thick, well-sorted, clastsupported, pebbly-cobbly gravel facies that shows a sharp conformable basal contact and horizontal bedding. The clasts show distinct b-axis imbrication towards the north and a-transverse-oriented pebbles. At the base of the unit, the stratification consists of a decimetre-thick sand layer $(\mathrm{Sm})$ with water escape structures. This sand bed was sampled for OSL age determination (Hel-TL04344, Table 2).

The underlying succession is unconformably overlain in both Kärväsniemi sections by a $60-\mathrm{cm}$ thick (KN-1) to 1 -m-thick $(\mathrm{KN}-2)$, brown diamicton bed (Unit $8(\mathrm{Dmm})$ ). The diamicton is massive, supported by a sandy matrix with scattered small pebble-sized clasts that in some cases have a clay coating. Sand lenses are occasionally present. The diamicton unit in $\mathrm{KN}-1$ yields sporadic large boulders on top of the unit. Fabric measured in $\mathrm{KN}-1$ indicated a preferred orientation of clasts from $295^{\circ}$.

With a sharp, conformable contact, the succession is overlain by $10-20 \mathrm{~cm}$ of poorly sorted gravel (Unit 9, Gm) with an undisturbed soil horizon on top.

Interpretation - Although fabric was not obtained, the massive structure and poor sorting, high degree of compactness, and the persistent nature of the lowermost diamicton (Unit 1) indicates deposition in a subglacial environment, probably by lodgement (cf. Dreimanis, 1989). The overlying sequence of gravels and sands (Units $2-4)$ is interpreted as recording deposition in an ice-marginal environment; the units are composed of a mixture of sediments deposited by streams draining the from the glacier (Units 2 and 4) and of frontal gravity flow deposits (Unit 3). The trough cross-stratified bed within the uppermost part of Unit 4 indicates a remnant of migrating 3D dunes. The decreasing grain size in the overlying sediment succession (Unit 5) with ripple-bedded and planeparallel bedded sands and silts, together with the out-of-size clasts deforming the underlying sandy layers, indicate deposition in a more distal proglacial basin. The presence of podsol soil and an ice-wedge cast within the topmost part of Unit 5 indicates sub-aerial exposure of the deposits in a dry and cold climate. On the basis of the strong erosional basal contact, sediment texture and fabrics, the diamicton (Unit 6) overlying the sorted 
sediments is interpreted as a response to a glacier advance from the NNE across the area and the deposition of till bed. In the overlying Unit 7, the well-sorted, clast-supported, horizontally stratified gravels and the presence of imbricated clasts indicates deposition taking place as a bedload lag or a fluvial bar within a braided environment (Miall, 1978). Based on the imbricated clasts and the presence of a-axis transverse pebbles, the palaeoflow points towards the south.

The presence of lenses of sorted sediments, the loose packing, the well-developed fabrics and the absence of basal erosion suggest that the massive, matrix-supported diamicton (Unit 8) was deposited by in situ melt-out of a nearly stagnant glacier (cf. Shaw, 1979). The topmost tabular gravels (Unit 9) extending throughout the Kärväsniemi quarry are interpreted as deglacial outwash, with high-energy braided stream deposits, well depicted in the LiDAR images.

\subsubsection{Hietakangas and Multaharju}

Two shallow sections in Hietakangas (HI-1) and Multaharju (MU-1) (Fig. 5) were examined to obtain age estimations for deglaciation and to investigate the origin of sandy deposits typical of the area (Räisänen, 2014).

The Hietakangas section is located in Sahankangas, classified as an extramarginal formation by Räisänen (2014). The LiDAR image (Fig. 3b) displays NE-oriented channels and bars, indicating typical geomorphological features for a braided river plateau. The Hietakangas plateau is 184 $186 \mathrm{~m}$ a.s.l. and the base level of the site is ca. 183 $\mathrm{m}$ a.s.l. The studied section was excavated on the intact $\mathrm{N}$ side of a sand pit. The section displays one single unit (Unit 1, $S p / G p$ ), $90 \mathrm{~cm}$ in thickness, which shows planar cross-bedding with bedsets that are $10-40 \mathrm{~cm}$ thick and dip angles ranging from 5 to $30^{\circ}$, indicating a palaeocurrent direction towards the south. The unit is capped by $20 \mathrm{~cm}$ of planar or sub-horizontal, well-sorted coarse sand. One OSL

\section{HI-1 Hietakangas}

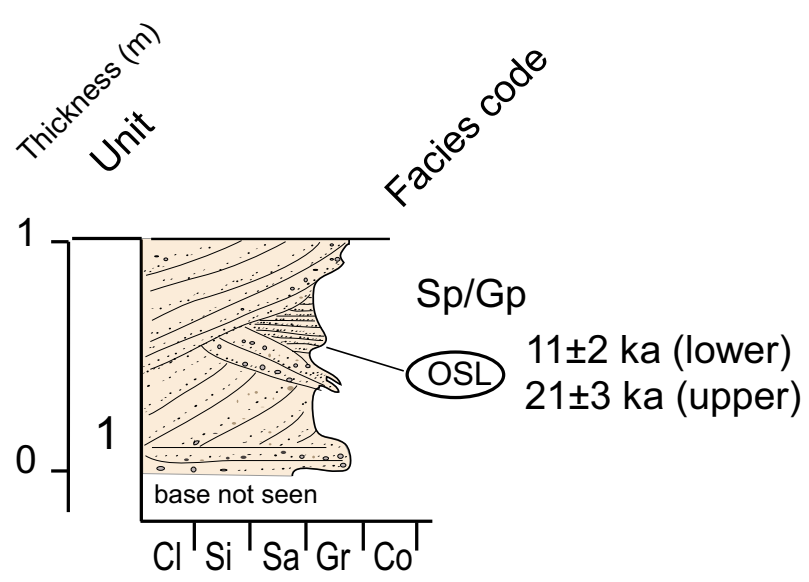

\section{MU-1 Multaharju}

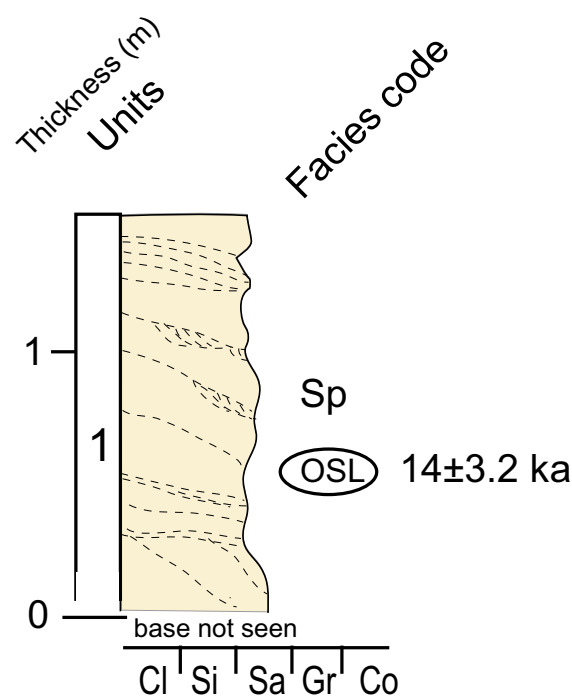

Figure 5. Two hand-dug sections, Hietakangas and Multaharju, represent surficial sandy deposits of the area. Location depicted in Figs. 2 and 3. 
sample (Hel-TL04301, Table 2) was collected for age determination. The base of the unit was not observed.

Interpretation - The planar cross-bedded sand and pebbly sand are interpreted as remnants of downward-migrating 2D dunes in a braided river environment, confirmed by the LiDAR images.

The Multaharju site (MU-1) represents a longitudinal ridge (Fig. 3c) composed of well-sorted fine sand, and interpreted as an aeolian dune by Räisänen (2014). The studied ridge rises 2 metres from its surroundings and has an altitude of $190 \mathrm{~m}$ a.s.l. The outcrop that was examined and sampled provides ca. $1.6 \mathrm{~m}$ of vertical section, consisting of well-sorted fine to medium-grained sand (Unit $1(S p)$ ). The sands display planar cross-stratification in sets ranging from $10 \mathrm{~cm}$ to several decimetres in thickness and indicating a northerly to northeasterly flow. One OSL sample (Hel-TL04302, Table 2) was obtained from the middle part of the fine sand unit.

Interpretation - The planar cross-bedded structure and well-sorted fine sand indicate an aeolian origin, supporting the interpretation based on the LiDAR image. Based on its morphology and the plunge of the foreset beds (Fig. 3c), the prevailing wind direction has been from the SSW.

\subsubsection{Kuusivaara}

Three representative sections (KU-1-KU-3) studied along the southern side of Kuusivaara hill expose diamicton units and bedrock adjacent to the River Kitinen valley (Fig. 6). The LiDAR image reveals a drainage channel pattern covering altitudes of 196-220 m a.s.l. and debris flow deposits on the southern hillslope and across Kuusivaara hill (Fig. 3d).

The bedrock was reached in sections KU-1 and KU-2. In KU-1, a reddish, massive, up to 1.3-m-thick diamicton unit (Unit 1, $\operatorname{Dmm}(d)$ ), composed of chemically weathered clasts with a high content of clayey matrix and draped by a cobbly-bouldery pavement, overlies deeply weathered bedrock with a sharp basal contact. The number of fresh diamicton clasts increases upwards; the clasts have a reddish clay coating.

A reddish, firm, matrix-supported, silty diamicton (Unit 2, Dmm) was observed in KU-3. The diamicton unit contains abundant subrounded clasts, ca. $5 \mathrm{~cm}$ in diameter, and the fabrics show a strong preferred orientation from NNW, with the mean fabric orientation being $315^{\circ}$. The unit attains a thickness of $60 \mathrm{~cm}$ in KU-3, but its lower contact could not be observed.

Unit 3 (Sm, P). The lower diamicton is conformably overlain by medium-grained massive sand, $30 \mathrm{~cm}$ in thickness, in which remnants of deformed organic, eluvial and enrichment soil horizons were observed in KU-3 (Fig. 4). The sand unit was sampled for OSL age determination (HelTL04340).

A grey, clast-supported diamicton bed (Unit 4, $\operatorname{Dmm}(s)), 1-2 \mathrm{~m}$ in thickness, was observed in all Kuusivaara sections. It is clast-supported diamicton at the base, mixed with gravelly matrix, the clasts being coated with reddish fine material. Upwards, the unit grades into a loose, more massive and sandy diamicton containing numerous lenses of sorted sand. Pebble-sized clasts $(1-5 \mathrm{~cm})$ are only occasionally present; the fabric is poorly developed.

The diamicton bed is overlain in KU-1 by subhorizontally stratified well-sorted sands, roughly $50 \mathrm{~cm}$ thick (Unit 5, Sh). The contact between these two units appears as a well-defined clast pavement, draped by a massive silt layer. The sedimentary succession is capped by $0.2 \mathrm{~m}$ of organic soil (Unit G).

Interpretation - The sections observed on the southern slope of Kuusivaara represent a series from weathered bedrock on the bottom to peat deposits on the top. The weathered bedrock observed is of the saprock type, showing undisturbed and interlocking angular rubble in which chemical alteration is mainly confined to the surfaces of otherwise hard blocks (Hall et al., 2015).

The weathered bedrock material mixed with diamicton (Unit 1), in which the proportion of eroded saprock material decreases upwards, can be interpreted to represent deformation till, deposited by an advancing glacier. The reddish diamicton 


\section{KU-1 Kuusivaara KU-2 Kuusivaara}

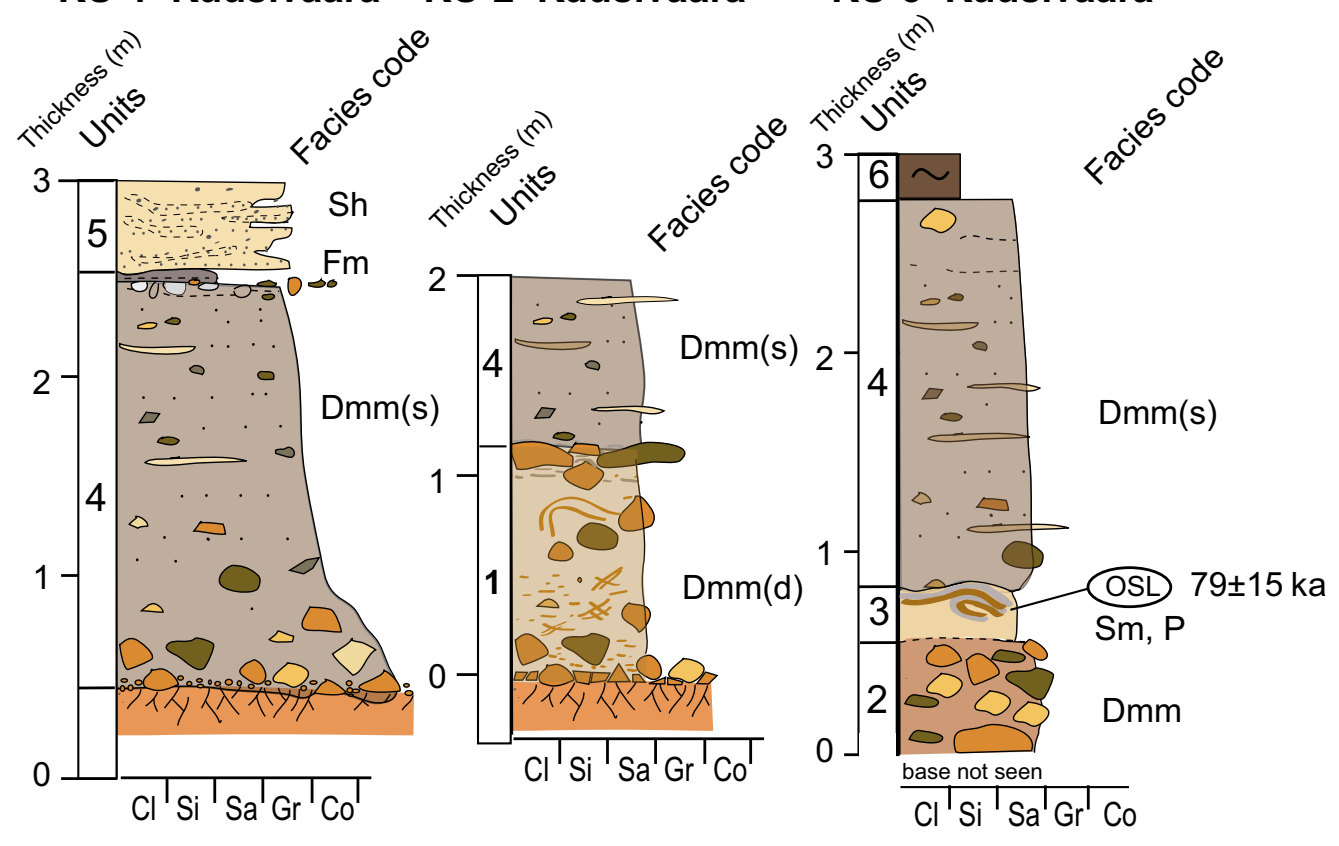

Figure 6. Sections studied along the Kuusivaara road. Location depicted Figure 2 and 3.

(Unit 2) described from the KU-3 section, with poor sorting, well-developed fabric $\left(\right.$ c. $\left.315^{\circ}\right)$ and a massive structure, is interpreted as direct evidence of lodgement processes. The overlying massive sand (Unit 3) in KU-3 displaying distinct remnants of deformed soil horizons indicates subaerial exposure and can therefore be interpreted to represent palaeosol. The presence of lenses of sorted sediments, the loose packing and the coarser texture compared to the diamicton units below, as well as the absence of basal erosion, are all features suggesting that Unit 4 was probably deposited by melt-out processes; the weak preferred orientation of clasts indicates disturbance during or after the formation of the till (cf. Shaw, 1982).

Upwards, the presence of imbricated clasts and subhorizontally stratified sands (Unit 5) indicates deposition taking place as a bedload lag and traction currents, possibly connected to deglaciation and the development of Moskujärvi Ice Lake and the ancient River Kitinen. The peat on top (Unit 6) represents modern soil.

\subsection{Ice-flow directions detected from the LiDAR-based DEM and fabric analysis of till beds}

The lineated terrains within the three selected areas are presented in Fig. 7. The glacial lineations are abundant in the Kittilä $(\mathrm{n}=173)$ and Salla $(\mathrm{n}=244)$ areas, where they mainly consist of welldefined and persistent drumlins or drumlinoids, often 1-2 kilometres (on average $1.2 \mathrm{~km}$ ) in length. The lineations are scarcer $(\mathrm{n}=18)$ and less well developed in the Sodankylä area, where only a few lineations, mainly drumlins or undefined glacial lineations with an average length of 800 metres, are present, and the landforms largely consist of valleys covered with Quaternary sediments and nonstreamlined inselbergs. A distinct NNW orientation of the lineations is visible both in Kittilä $\left(320-330^{\circ}\right)$ and in Salla $\left(330-350^{\circ}\right)$, whereas in the Sodankylä area, the streamlined features show a more diverse pattern with equal orientations of ca. 240, 315 and $340^{\circ}$ (Fig. 8). 


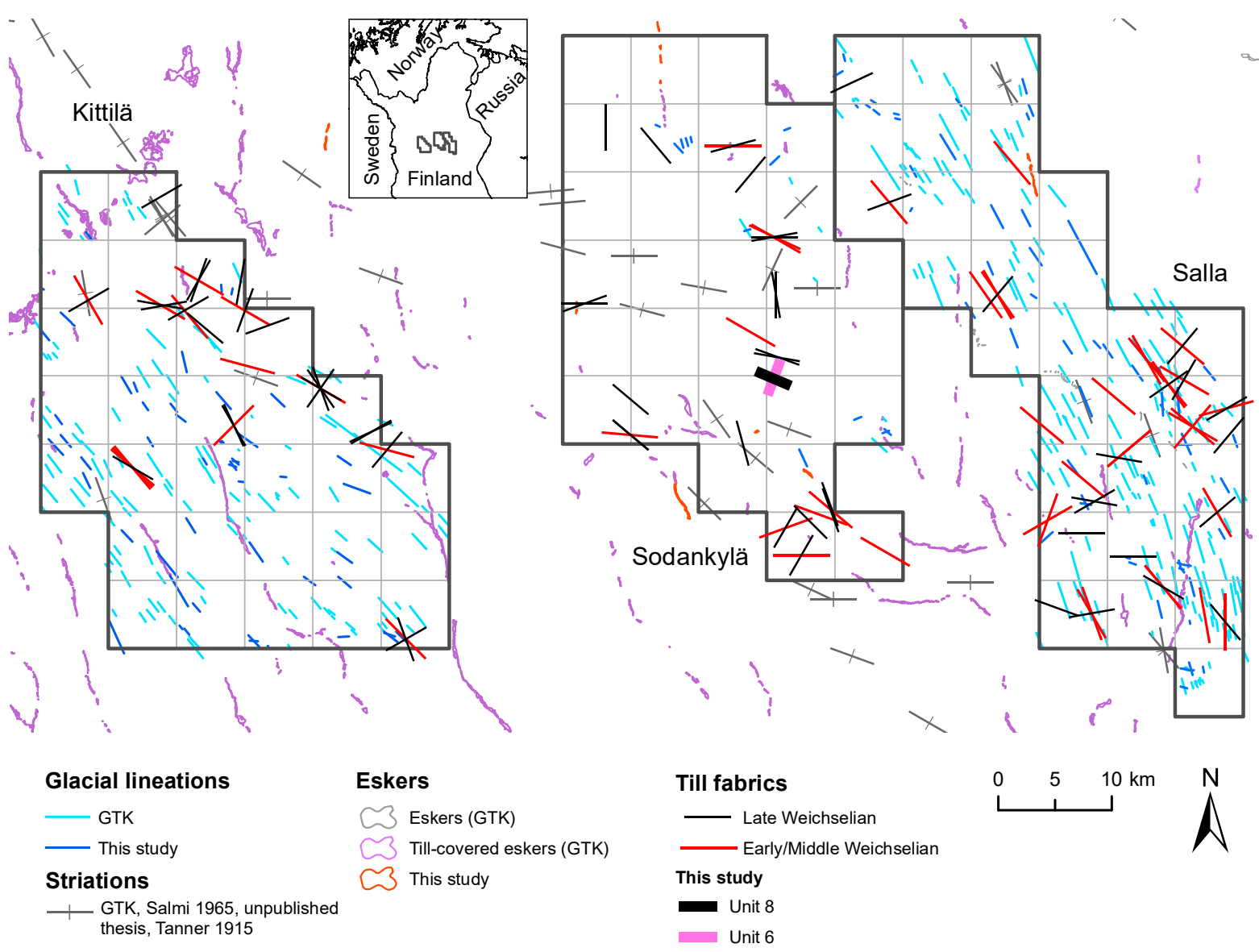

Figure 7. Glacial lineations, striations and till fabric analyses from the three mapped areas in central Finnish Lapland: Kittilä, Sodankylä and Salla (coverage $1080 \mathrm{~km} \mathrm{~km}{ }^{2}$ for each). Administrative borders of Finland: (c) modified and reproduced after the National Land Survey of Finland, 2016. Administrative borders of Norway, Russia and Sweden: www. gadm.org (visited 4/2017).

The striations observed in the studied area are few in number $(n=18)$ but show less spatial variability through the three areas compared with the lineated terrain orientations (Figs 7 and 8). However, the Kittilä region shows a more scattered pattern.

Eskers are present in the entire mapped region. In the Sodankylä area and in Salla, a north-south orientation is particularly apparent, whereas in the Kittilä region, eskers orientated NNW dominate. In the Salla region, the eskers are classified as eskers and till-covered eskers (cf. Sutinen, 1992; Johansson, 1995; Johansson \& Kujansuu, 2005), respectively assumed to represent Late Weichselian and Early/
Middle Weichselian landforms. The $\mathrm{N}$ orientation is distinct, especially in the till-covered esker class, whereas the assumed younger eskers show no preferred orientation (Fig. 7), but are dominantly $(84.6 \%)$ zigzag shaped and dissected.

Till fabric analyses $(n=116)$ (Fig. 8) are classified here following their original interpretation and stratigraphic position into two age categories: 1) Late Weichselian and 2) Early/Middle Weichselian. In the Kittilä and the Salla areas, the Late Weichselian till fabric shows a WSW orientation and the lower till beds a NNW orientation. In the Sodankylä area, fabric analyses of the Late Weichselian till beds revealed no clear orientation, 
Kittilä

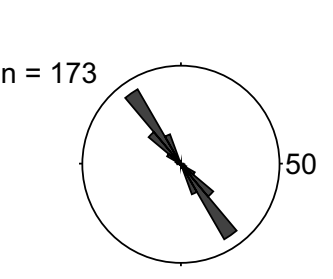

Late

Weichselian
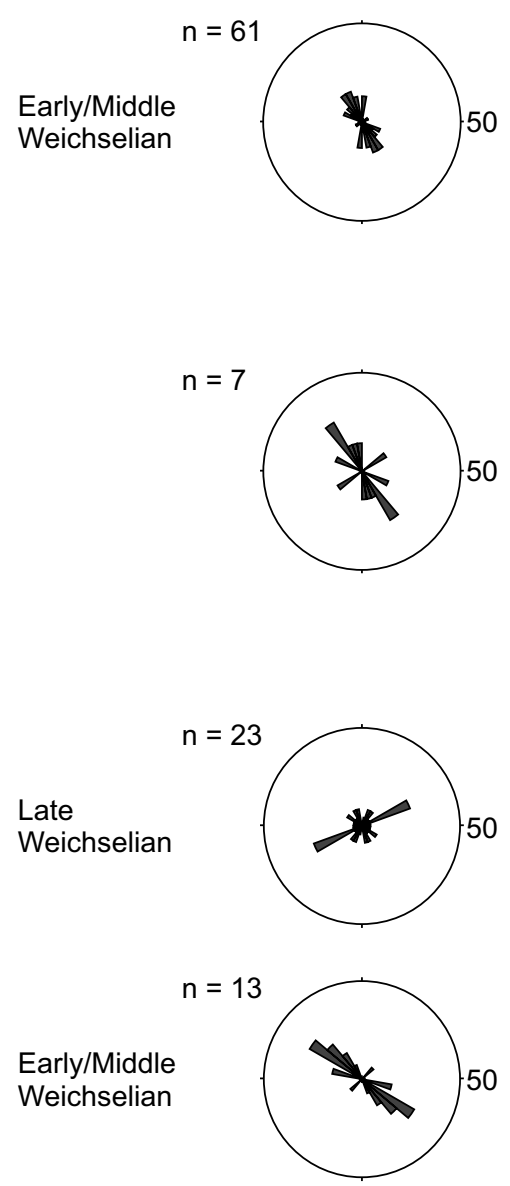

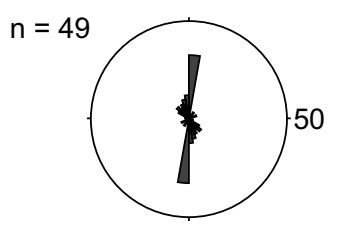

Striations
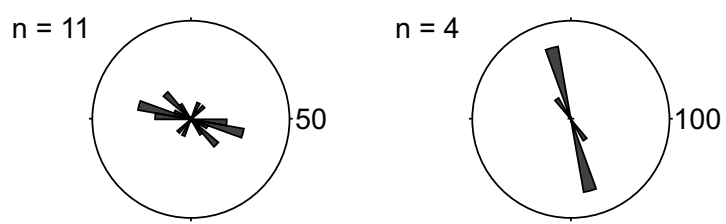

Till fabrics

Sodankylä

Salla

\section{Glacial lineations}
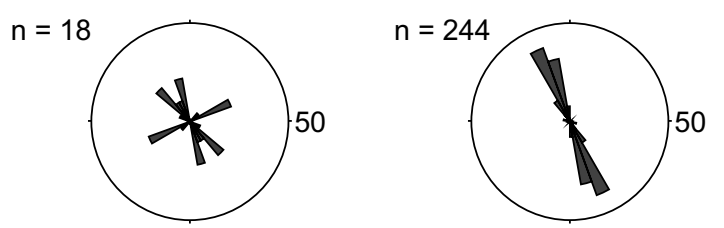

\section{Eskers}
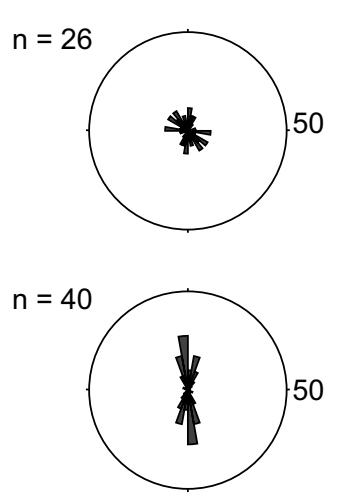

$\mathrm{n}=18$
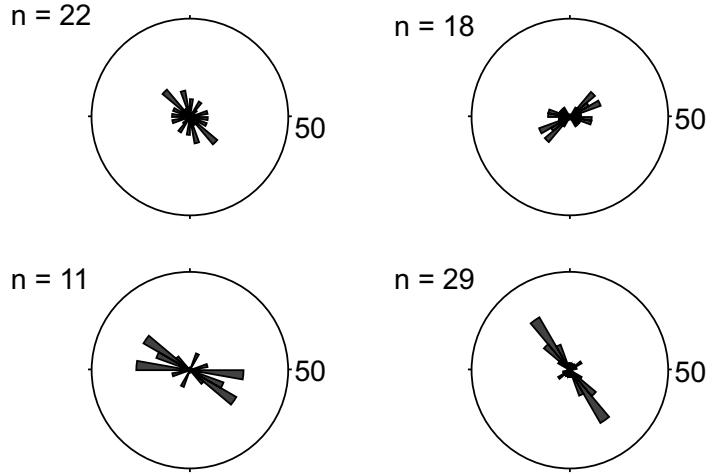

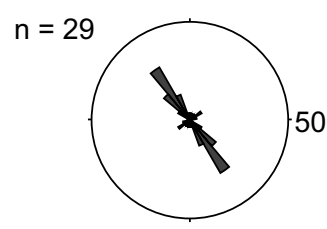

Figure 8. A flow direction analysis of features indicative of glacial flow directions within the three mapped areas, Kittilä, Sodankylä and Salla, presented in Fig. 7. The numbers 50 and 100 indicate the value (as a \% of the total) for the perimeter. 
but clast fabrics for the lower till (Early/Middle Weichselian) indicate ice flow from the ENE.

Interpretation - The WSW orientation of the Late Weichselian till fabric is visible in neither eskers nor other glacial lineations (i.e. streamlined features), suggesting weak erosion and/or deposition during the Late Weichselian. The most notable features in the mapped region are the aligned streamlined features with the Early Weichselian till fabric, indicating that glaciation(s) predating the Late Weichselian was more pronounced in the study area. The orientation of eskers, especially in the Sodankylä and Salla areas, appears to be inclined 10$20^{\circ}$ eastwards from the main glacial flow directions inferred from the lineations. This may provide evidence for a Middle Weichselian glacial advance.

The Early/Middle Weichselian till fabrics and orientation of till-covered eskers with a uniform NNW pattern in both the Kittilä and Salla areas define an ice-divide zone north of the study area. As for the Late Weichselian till fabrics, the dominant ice-flow directions were from WSW, indicating a westerly ice-divide zone. The inferred Early Weichselian ice flow directions in the Kittilä and Salla areas are slightly different, which may imply the past presence of two ice lobes or ice streams, whereas the Sodankylä area, with its scarce streamlined features and more divergent till fabrics, may reflect an interlobate position between the two lobes during the Early Weichselian.

\subsection{OSL age determination results and their interpretation}

The measured palaeodoses and the suggested OSL ages of the samples are presented in Table 2. The measured background radiation was low, varying within $0.064-0.075 \mu \mathrm{Sv} / \mathrm{h}$. However, the bimodal palaeodose distribution of two of the samples, HelTL04301 from Hietakangas and Hel-TL04344 from Kärväsniemi, suggests incomplete bleaching of the sample or two age population samples.

The OSL results from studied sites provide ages that range from 79 to $11 \mathrm{ka}$. They form three age groups, most of the samples falling to Early
Weichselian, one sample to Middle Weichselian and the rest representing Late Weichselian. The samples from the sand-rich sediments in Kärväsniemi (Units 4 and 5) and palaeosol in Kuusivaara (Unit 3) yield ages of 79-67 ka (Table 2, Figs 4-6) indicating deposition during Early Weichselian. The fluvial sand unit in Kärväsniemi (Unit 7) yield a bimodal age distribution of 41 and $73 \mathrm{ka}$. The Middle Weicselian age $(41 \mathrm{ka})$ represents obviously bestzeroed sample compared with the older one. The youngest set of samples were obtained from Hietakangas and Multaharju. Of these two sites, fluvial sand in Hietakangas yield a bimodal age distribution of 21 and $11 \mathrm{ka}$, while an age of $14 \mathrm{ka}$ was obtained from the aeolian sand in Multaharju.

\section{Discussion}

The chronology and correlation of the studied sequences are based on their lithological characteristics and their stratigraphic and lateral relationships, along with OSL numerical age estimates. Despite the complexity and fragmentary nature of the deposits, a sequence of glacial and interstadial events in the sedimentary succession is apparent.

\subsection{Weathering crust and deposits related to the Early Weichselian}

Weathered saprolite bedrock was encountered in two Kuusivaara pits (Fig. 6). Although not uniformly distributed, it is likely that most sections presented in this study have more or less weathered bedrock at the base, since earlier studies have proven it to be abundant in the River Kitinen valley (Leskelä, 1971; Salminen, 1972; Hirvas, 1991; Hall et al., 2015). The thickness of weathered bedrock reported in the area varies from a few metres to over $40 \mathrm{~m}$ observed in Sahankangas (Åberg et al., 2017). The presence of remnants of weathered bedrock mantle in areas that have undergone several glaciations is considered to indicate weak glacial erosion due to a nearly stagnant ice sheet in the middle of an ice-divide zone (Ebert, et al., 2015). 
The weathered bedrock is overlain in Kuusivaara by deformation and lodgement till beds deposited by an advancing glacier (Fig. 6). Based on their stratigraphic position, the lowermost till beds of Kuusivaara correspond to the extensive and uniform till (Unit 1, Fig. 3) encountered in the Kärväsniemi sections. A correlation of this lowermost lodgement till with the Early Weichselian till bed III (Hirvas, 1991) and lower till in Kevitsa (Hirvas et al., 1994) is possible due to its strong NW fabrics, along with its characteristic reddish-brown colour derived from the underlying weathered bedrock, as described in Kittilä by Peuraniemi (1989). This NW flow direction is widely accepted to represent an Early Weichselian flow phase (e.g. Hirvas, 1991; Johansson \& Kujansuu, 2005). The streamlined feature pattern visible in the DEM coincides with the orientation of the Early/Middle Weichselian till fabric, providing further support for the strong depositional and erosional effect of the earlier stadials compared to that of the Late Weichselian. The correlation of this lowermost till unit to the Early Weichselian has a degree of uncertainty due to the lack of exposure and chronological tie points of the deposits underlying the basal till. Therefore, a pre-Weichselian age cannot be excluded.

The OSL ages from the overlying palaeosol suggest that this ice advance predated the Odderade interstadial and probably occurred during the Rederstall Stadial (MIS 5b). The Early Weichselian till is overlain by sediments representing an ice-free environment, including fluvial and cover sands with distinct soil horizons and remnants of frost activity in the upper part of the succession (Figs 3 and 6). Four OSL age determinations were obtained from these units: two samples from the sands of Unit 4 yielded ages of $79 \mathrm{ka}(\mathrm{KN}-1)$ and $75 \mathrm{ka}(\mathrm{KN}-2)$, whilst the palaeosols in Kuusivaara (KU-3 Unit 3) and Kärväsniemi (KN-2 Unit 5) gave ages of 79 and $67 \mathrm{ka}$, respectively. Based on these ages, it is apparent that sedimentation of the sand units can be related to the Odderade interstadial (MIS 5a); the ages also fall close to those (89.5-74.2 ka) reported from the nearby Pirttikangas and Ukonharju sites (Sarala et al., 2015). These sands (KN-2, Unit 5) probably represent the same interstadial that has been named as the Maaselkä (Fig. 1) interstadial by Hirvas (1991).

\subsection{Middle Weichselian}

Sands correlated with Odderade (MIS 5a) are overlain by a thin, compacted diamicton unit (Fig. 3; Unit 6, KN-2) that is interpreted as lodgement till. Based on the OSL results for the surrounding sorted sediments (40 and $67 \mathrm{ka}$ ), this diamicton was deposited by MIS 4 glaciation, which also deposited the diamicton unit Savukoski 3 in the Sokli sequence, with OSL ages of 45-48 $\mathrm{ka}$ and 74-80 ka from surrounding sediments (Helmens, 2014; Helmens et al., 2018) in eastern Finnish Lapland, and the lower Middle Weichselian diamicton unit in Hannukainen and Rautuvaara, western Finnish Lapland (Howett et al., 2015; Lunkka et al. 2015). According to two fabric measurements and one observation of a striated boulder, the unit was deposited by a glacier flowing from the north-northeast. Therefore, the till unit can be compared with a similar lithostratigraphic unit found earlier by Johansson (1995) from Savukoski in eastern Lapland, which was described as a thin, compact till deposited by a glacier flowing from the north-northeast. The lineations and till fabric in general suggest a more N-NE-sourced ice flow, but the orientation of the eskers, especially those with a till cover (Sutinen, 1992; Johansson, 1995; Johansson \& Kujansuu, 2005) examined in this study from the DEM, show an ice-flow direction from north. Johansson (1995) named the unit as the "Old Northern till" and correlated it with the Middle Weichselian. In addition, a Middle Weichselian glacier flow direction from the north was also observed as the deposition of the "Suas till" in Kittilä, NW Lapland (Sutinen, 1992, and references therein). A southward-flowing ice flow has also been detected from the till overlaying the Maaselkä interstadial material (Rossi, 1991; Hirvas, 1991). Some of the southwards-oriented ice-flow directions reported by Hirvas (1991) might relate to the Middle Weichselian instead of the 
Late Weichselian, as suggested by the author. To conclude, this study, supported by the studies of Sutinen (1992), Johansson (1995) and Salonen et al. (2014), suggests that the main ice flow during the first glacial advance of the Middle Weichselian (MIS 4) was initiated in northern Scandinavia, continuing along the Gulf of Bothnia towards the south (e.g. Kleman et al. 1997; Räsänen et al., 2015). Furthermore, this would indicate that the ice-divide zone during the Middle Weichselian was situated north of the study area.

Earlier studies suggest either one or two glacial advances during the Middle Weichselian, the first of which occurred during MIS 4 (ca. 60-50 ka) and the second during MIS 3 (ca. $40 \mathrm{ka}$ ) (Sutinen, 1992; Johansson, 1995; Helmens, 2014; Salonen et al., 2014; Howett et al., 2015; Lunkka et al., 2015; Helmens et al., 2018). The glacial advance during MIS 4 has received the more extensive coverage of the two, the interpretations varying from an ice sheet covering the whole of Finland (e.g. Svendsen et al., 2004; Sarala et al., 2005) to ice coverage only in northern Finland and the Gulf of Bothnia (Kleman et al., 1997; Räsänen et al., 2015). Sedimentological evidence for the younger Middle Weichselian glaciation (MIS 3 glaciation) is found in western Finnish Lapland (Hannukainen and Rautuvaara), where two diamicton units (corresponding to MIS 4 and MIS 3, respectively) are separated by sorted deposits (Salonen et al., 2014; Lunkka et al., 2015). Since there is no indication of two separate Middle Weichselian tills in central Finnish Lapland, it is likely that the coverage of the MIS 3 ice sheet only reached western Finnish Lapland, as Lunkka et al. (2015) suggested.

In Kärväsniemi, the Middle Weichselian tills are overlain by horizontally stratified gravels (Fig. 3; Unit 7, KN-2) that were laid down in a fluvial channel environment without sedimentological indications of glacier activity. The sand lens at the base yielded a bimodal luminescence peak with ages of $41 \pm 9$ and $73 \pm 12 \mathrm{ka}$, most likely indicating incomplete bleaching of grains in the older age population. The younger age generation of 41 ka correlates with the Middle Weichselian inter- stadial (MIS 3), and the fluvial unit can therefore be further connected with the Tulppio interstadial in Sokli (Helmens, 2014) and either of the MIS 3 interstadials in Hannukainen and Rautuvaara (Salonen et al., 2014; Lunkka et al., 2015). The interstadial around $40 \mathrm{ka}$ is further supported by a radiocarbon-dated deer (Rangifer tarandus) horn found from Tornio, western Finnish Lapland, suggesting an age of 37-41 ka. (Siivonen 1975). To date, the only other Middle Weichselian interstadial site in Sodankylä lies in Ruosselkä (Putkinen et al., 2020), with an OSL age of $46 \pm 6 \mathrm{ka}$.

\subsection{Late Weichselian}

Late Weichselian till beds are widely distributed in Finnish Lapland, labelled as till beds I and II by Hirvas (1991). The sections presented in this study indicate that the upper till (Unit 8 in $\mathrm{KN}-1$ and $\mathrm{KN}-2$ and Unit 4 in KU-1-3) was deposited by melt-out processes. This till forms a thin, patchy and blocky morainic veneer within the River Kitinen valley. Based on its stratigraphic position and the OSL age of $41 \mathrm{ka}$ from the underlying sorted sediment, the uppermost till unit in Kärväsniemi (Unit 8, KN-1 and KN-2) and Kuusivaara (Unit 4, KU-1-3) can be correlated with the Late Weichselian till beds I or II in Finnish Lapland (Hirvas, 1991), the upper till in Rautuvaara and Hannukainen in western Finnish Lapland (Salonen et al., 2014; Lunkka et al., 2015), Savukoski 4 in Sokli, eastern Finnish Lapland (Helmens, 2014), and the till bed covering the glaciofluvial deposits in Ukonharju and Pirttikenttä Sarala et al. (2015) (see location in Fig. 1).

The study area is located directly south of the Kolari-Kittilä-Saariselkä ice-divide zone (cf. Johansson et al., 2011; Sarala, 2005; Putkinen et al., 2017) separating the Salla and Kittilä ice stream lobes in the south from the Inari and Enontekiö ice stream lobes in the north. This ice-divide zone, characterised by deep weathering and weak glacial erosion (Penttilä, 1963; Hirvas, 1991; Ebert et al., 2015; Hall et al., 2015), has conventionally been connected with the Late Weichselian glaciation 
(Sarala 2005, Johansson et al., 2011). However, the ice-flow directions inferred from the Late Weicheslian till fabrics point to ice streams supplied from a westerly/southwesterly source, in concert with Kleman et al. 1997 (Fig. 4), placing the ice divide of the last glacial maximum in the Gulf of Bothnia. In contrast, the N-NW Early/Middle Weichselian till fabrics and the associated glacial lineations in the mapped region suggest that the Kolari-Kittilä-Saariselkä ice-divide zone may rather be linked to an Early/Middle Weichselian glaciation.

The Last Glacial Maximum (LGM) of the Scandinavian Ice Sheet occurred at 23-21 ka (e.g. Hughes, et al. 2016). However, the maximum extent of the SIS was not synchronous throughout the area of its occupancy. Considerable evidence exists that central Finnish Lapland was ice free soon after the onset of the Holocene (Dated-1 dataset in Hughes et al., 2016). Two deglaciation ages obtained in this study suggest the minimum age of the local deglaciation to be $11 \pm 2 \mathrm{ka}$ (Hel-TL04301, Table 2), which is supported by the age of the basal peat in nearby Postoaapa, reported as 10350 years ago (Mäkilä et al., 2013). However, the deglaciation age obtained from the Multaharju aeolian deposits

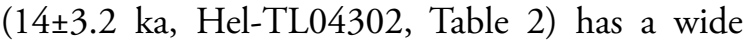
scatter, and the median age is older than expected (Johansson \& Kujansuu, 2005; Hughes et al., 2016), which might reflect poor bleaching of the material. In addition to the OSL date in this study, several age determinations indicating pre-Holocene ice-free environments have been reported from northern Finland: 16.4 ka from Lake Sompiojärvi, Sodankylä (Jungner, 1979); two dates of 13.3. ka and $12.4 \mathrm{ka}$ from a sediment core from Pieni Kankaanlampi, Kemijärvi; 12.4 ka (Heikkinen et al., 1974) and $12.9 \mathrm{ka}$ (Nydahl et al., 1972) from Parvavuoma, Kittilä; and 11.9 ka from Lompolojärvi, Pello (Jungner and Sonninen, 1983). Deglaciation of the SIS was rapid during the Bølling-Allerød warm period, which is demonstrated by the rapid retreat of the SIS southern margin (e.g. Hughes et al., 2016). The abundance of suggested dates for pre-Holocene ice-free conditions in Finnish Lapland implies that the melting of the SIS might also have been notable in the northern part of the SIS. If the dates are reliable, this suggests that the SIS did not prevail as a uniform ice sheet in the northern part of the SIS during the Bølling-Allerød warm period, but rather as scattered local glaciers with only modest thicknesses.

\section{Concluding remarks}

The studied succession in Sodankylä provides evidence of three Weichselian glacial events, in the Early (MIS 5b), Middle (MIS 4) and Late (MIS 2) Weichselian, and ice-free conditions during the intervening Odderade (5a) and MIS 3 interstadials.

- The current topography reflects pre Late Weichselian glacial flow directions rather than those of the Late Weichselian.

- This study suggests a northern location for the ice-divide zone during the Early/Middle Weichselian, and a more western-southwestern position for the Late Weichselian.

- The OSL age determination points to ice-free areas in the vicinity of the River Kitinen during the Bølling-Allerod warm period, resulting from a patchy ice cover or rapid deglaciation

\section{Acknowledgements}

Financial support was mainly provided by the K.H. Renlund Foundation, with additional funding from the University of Helsinki projects Sakatti TFM and Sakatti GPR, and the Doctoral Programme in Geosciences (GeoDoc). We thank Susanne Åberg, Kirsti Korkka-Niemi and Niko Putkinen for discussions, and Jyri Laakso, Tatu Lahtinen and Markus Valkama for assistance during the fieldwork campaigns in 2015/2017. Fieldwork was made possible through collaboration with the AA Sakatti Mining Oy, particularly with Anne Rautio, Jukka Jokela, Janne Siikaluoma and Joanna Kuntonenvan't Riet. We are grateful to Philip Gibbard, Jukka Pekka Palmu and the editor Kuosmanen for their constructive and helpful reviews. 


\section{Supplementary Data}

Electronic Appendices A-E for this article are available via Bulletin of the Geological Society of Finland web page.

\section{References}

Aalto, M., Eriksson, B. \& Hirvas, H., 1992. Naakenavaara interglacial - a till-covered peat deposit in western Finnish Lapland. Geological Society of Finland, Bulletin 64, 169181. https://doi.org/10.17741/bgsf/64.2.005

Aitken, M.J., 1985. Thermoluminescence dating. Studies on Archaeological Science. Academic Press Inc., London, 359 p.

Bøtter-Jensen, L. \& Duller, G.A.T., 1992. A new system for measuring optically stimulated luminescence from Quaternary samples. International Journal of Radiation Applications and Instrumentation. Part D. Nuclear Tracks and Radiation Measurements 20, 549-553. https://doi.org/10.1016/1359-0189(92)90003-E

Bøtter-Jensen, L. \& Mejdahl, V., 1988. Assessment of beta dose-rate using a GM multicounter system. International Journal of Radiation Applications and Instrumentation. Part D. Nuclear Tracks and Radiation Measurements 14, 187-191. https://doi.org/10.1016/1359-0189(88)90062-3

Bøtter-Jensen, L., Duller, G.AT., Murray, A. \& Banerjee, D., 1999. Blue Light Emitting Diodes for Optical Stimulation of Quartz in Retrospective Dosimetry and Dating. Radiation Protection Dosimetry 84, 335-340. https://doi.org/10.1093/oxfordjournals.rpd.a032750

Dreimanis, A., 1989. Tills: their genetic terminology and classification. In: Goldthwait R.P., \& Matsch C.L. (eds.), Genetic Classification of Glacigenic Deposits, Balkema, Rotterdam, pp. 17-84. https://doi.org/10.1017/S0016756800013960

Ebert, K., Hall, A. M., Kleman, J. \& Andersson, J., 2015. Unequal ice-sheet erosional impacts across low-relief shield terrain in northern Fennoscandia. Geomorphology 233, 64-74. http://dx.doi.org/10.1016/j.geomorph.2014.09.024

Eyles, N., Eyles, C.H. \& Miall, A.D., 1983. Lithofacies types and vertical profile models; an alternative approach to the description and environmental interpretation of glacial diamict and diamictite sequences. Sedimentology 30, 393-410. https://doi.org/10.1111/j.1365-3091.1983.tb00679.x

Hall A.M., Sarala P. \& Ebert K., 2015. Late Cenozoic deep weathering patterns on the Fennoscandian shield in northern Finland: A window on ice sheet bed conditions at the onset of Northern Hemisphere glaciation. Geomorphology 246, 472-488.

https://doi.org/10.1016/j.geomorph.2015.06.037
Hanski, E. \& Huhma, H., 2005. Central Lapland greenstone belt. In: Lehtinen M., et al. (eds.), Precambrian Geology of Finland, Elsevier, Amsterdam, pp. 139-193.

Heikkinen, A., Koivisto, A. K. \& Äikää, O., 1974. Geological Survey of Finland, Radiocarbon measurements VI. Radiocarbon 16, 252-268.

Helmens, K. F., 2014. The Last Interglacial-Glacial cycle (MIS 5-2) re-examined based on long proxy records from central and northern Europe. Quaternary Science Reviews 86, 115-143. https://doi.org/10.1016/j.quascirev.2013.12.012

Helmens, K. F., Räsänen, M. E., Johansson, P. W., Jungner, H. \& Korjonen, K., 2000. The Last Interglacial-Glacial cycle in NE Fennoscandia: a nearly continuous record from Sokli (Finnish Lapland). Quaternary Science Reviews 19, 1605-1623. https://doi.org/10.1016/S0277-3791(00)00004-4

Helmens, K. F., Bos, J. A. A., Engels, S., van Meerbeeck, C., Bohncke, S. J. P, Renssen, H., Heiri, O., Brooks, S. J., Seppä, H., Birks, H. J. B. \& Wohlfarth, B., 2007a. Present-day temperatures in northern Scandinavia during the last glaciation. Geology 35, 987-990. https://doi.org/10.1130/G23995A.1

Helmens, K. F., Johansson, P. W., Räsänen, M., Alexanderson, H. \& Eskola, K. O. 2007b. Ice-free intervals continuing into Marine Isotope Stage 3 at Sokli in the central area of the Fennoscandian glaciations. Geological Society of Finland, Bulletin 79, 17-39. https://doi.org/10.17741/bgsf/79.1.002

Helmens, K. F., Katrantsiotis, C., Salonen, J.S., Shala, S., Bos, J. A. A., Engels, S., Kuosmanen N., Luoto T.P., Väliranta M., Luoto M., Ojala A., Risberg J. \& Weckström J., 2018. Warm summers and rich biotic communities during N-Hemisphere deglaciation. Global and Planetary Change 167, 61-73. https://doi.org/10.1016/j.gloplacha.2018.05.004

Hirvas, H., 1991. Pleistocene stratigraphy of Finnish Lapland, Geological Survey of Finland, Bulletin 354, 123 p.

Hirvas, H., Alfthan, A., Pulkkinen, E., Puranen, R. \& Tynni, R., 1977. Raportti malminetsintää palvelevasta maaperätutkimuksesta Pohjois-Suomessa vuosina 1972-1976. Summary: A report on glacial drift investigations for ore prospecting purposes in northern Finland 1972-1976. Geological Survey of Finland, Report of Investigation 19, $54 \mathrm{p}$.

Hirvas H., Saarnisto M., Hakala P., Huhta P., Johansson P. \& Pulkkinen E., 1994. Maaperän kerrosjärjestys ja geokemia Keivitsassa. Geological Survey of Finland, Report number 4320, 44 p. (in Finnish).

Howett, P. J., Salonen, V.-P., Hyttinen, O. S. M., KorkkaNiemi, K. I. \& Moreau, J., 2015. A hydrostratigraphical approach to support environmentally safe siting of a mining waste facility at Rautuvaara, Finland. Geological Society of Finland, Bulletin 87, 51-66.

https://doi.org/10.17741/bgsf/87.2.001

Hughes, A.L.C., Gyllencreutz, R., Lohne, Ø.S., Mangerud, J. \& Svendsen, J.I., 2016. The last Eurasian ice sheets - a 
chronological database and time-slice reconstruction, DATED-1. Boreas 45, 1-45.

https://doi.org/10.1111/bor.12142

Johansson, P., 1995. The deglaciation in the eastern part of the Weichselian ice divide in Finnish Lapland. Geological Survey of Finland, Bulletin 383, 72 p.

Johansson, P. \& Kujansuu, R., 2005. Quaternary deposits of Northern Finland - Explanation to the maps of Quaternary deposits 1:400000. Geological Survey of Finland, Espoo, 236 p. (in Finnish with English summary)

Johansson, P., Lunkka, J.P. \& Sarala, P., 2011. Glaciation of Finland. In: Ehlers, J. et al. (eds.), Quaternary glaciations - extent and chronology, a closer look, Developments in Quaternary Science 15, Elsevier, Amsterdam, pp. 105116.

Jungner, H., 1979: Radiocarbon dates I. Dating Laboratory, University of Helsinki, Finland, Report no. 1,77 p.

Jungner, H. \& Sonninen, E., 1983: Radiocarbon dates II. Radiocarbon Dating Laboratory, University of Helsinki, Report No 2, $121 \mathrm{p}$.

Kleman, J. \& Glasser, N. F., 2007. The subglacial thermal organisation (STO) of ice sheets. Quaternary Science Reviews 26, 585-597. https://doi.org/10.1016/j.quascirev.2006.12.010

Kleman, J., Hättestrand, C., Borgström, I. \& Stroeven, A., 1997. Fennoscandian palaeoglaciology reconstructed using a glacial geological inversion model. Journal of Glaciology 43, 283-299. https://doi.org/10.3189/S0022143000003233

Kujansuu, R., 1967. On the deglaciation of western Finnish Lapland. Bulletin de la Commission Géologique de Finlande, 232, $98 \mathrm{p}$.

Leskelä, S. 1971. Auger-kairaus Sodankylässä 5.7-24.7.1971. Geological Survey of Finland, Report number 1413, 7 p., 2 maps (in Finnish).

Lunkka, J. P., Sarala, P. \& Gibbard, P. L., 2015. The Rautuvaara section, western Finnish Lapland, revisited - new age constraints indicate a complex Scandinavian Ice Sheet history in northern Fennoscandia during the Weichselian Stage. Boreas 44, 68-80. https://doi.org/10.1111/bor.12088

Mäkilä, M., Säävuori, H., Kuznetsov, O. \& Grundström, A., 2013. Age and dynamics of peatlands in Finland. Geological Survey of Finland, Report of Peat Investigation 443, $41 \mathrm{p}$.

Mäkinen, K., 2005. Dating the Weichselian deposits of southwestern Finnish Lapland. In: Ojala, A. E. K. (ed.), Quaternary studies in the northern and Arctic regions in Finland: Proceedings of the workshop organized within the Finnish National Committee for Quaternary Research (INQUA) Kilpisjärvi Biological Station, Finland, January 13-14th 2005. Geological Survey of Finland, Special Paper vol. 40, pp. 67-78.

Miall A.D., 1978. Lithofacies types and vertical profile models in braided river deposits: a summary. In: Miall, A.D. (ed.),
Fluvial Sedimentology, Canadian Society of Petroleum Geologists, Memoir 5, pp. 597-604.

Murray, A. S. \& Wintle, A. G., 2000. Luminescence dating of quartz using an improved single-aliquot regenerativedose protocol. Radiation Measurements, 32, 57-73. https://doi.org/10.1016/S1350-4487(99)00253-X

Nydahl, R., Gulliksen, S. \& Lövseth, K., 1972. Trondheim natural radiocarbon measurements VI. Radiocarbon 14, 418-451. https://doi.org/10.1017/S0033822200059476

Penttilä, S., 1963. The deglaciation of the Laanila area, Finnish Lapland. Bulletin de la Commission Geologique de Finlande 203, $71 \mathrm{p}$.

Peuraniemi, V., 1989. Till stratigraphy and ice movement directions in the Kittila area, Finnish Lapland. Boreas 18, 145-157. https://doi.org/10.1111/j.1502-3885.1989.tb00385.x

Putkinen N., Eyles N., Putkinen S., Ojala A.E.K., Palmu J.-P., Sarala P., Väänänen T., Räisänen J., Saarelainen J., Ahtonen N., Rönty H., Kiiskinen A., Rauhaniemi T. \& Tervo T. 2017. High-resolution LiDAR mapping of glacial landforms and ice stream lobes in Finland. Geological Society of Finland, Bulletin 89, 64-81. https://doi.org/10.17741/bgsf/89.2.001

Putkinen, N., Sarala, P., Eyles, N., Daxberger, H., Pihlaja, J. \& Murray, A. 2020. Reworked Middle Pleistocene deposits preserved in the core region of the Fennoscandian Ice Sheet. Quaternary Science Advances 2: 100005. https://doi.org/10.1016/j.qsa.2020.100005

Räisänen, J., 2014. Sodankylän alueen maaperäkartoitus 20132014 (Väliraportti).Geological Survey of Finland, Report 52/2014, 22 p. (in Finnish).

Räsänen, M.E., Huitti, J.V., Bhattarai, S., Harvey, J. \& Huttunen, S. 2015. The SE sector of the Middle Weichselian Eurasian Ice Sheet was much smaller than assumed. Quaternary Science Reviews 122, 131-141. https://doi.org/10.1016/j.quascirev.2015.05.019

Rossi, S., 1991. Rapakallion kuparianomalian malmitutkimukset Maaselässä Sodankylän kunnan pohjoisosassa vuosina 1977-1983. Geological Survey of Finland, 48 p., 8 appendices (in Finnish).

Salmi, M. 1965. Sodankylän Sattasen glasiaaligeologiasta. M.Sc. Thesis, University of Oulu, Finland, 57 p., 2 appendices.

Salminen, R., 1972. Auger-kairaus Sodankylässä keväällä 1972. Geological Survey of Finland. 7.p., 24 appendices (in Finnish).

Salonen, V.-P., Moreau, J., Hyttinen, O. \& Eskola, K. O., 2014. Mid-Weichselian interstadial in Kolari, western Finnish Lapland. Boreas 43, 627-638. https://doi.org/10.1111/bor.12060

Sarala P., 2005. Weichselian stratigraphy, geomorphology and glacial dynamics in southern Finnish Lapland. Geological Society of Finland, Bulletin 77, 71-104. https://doi.org/10.17741/bgsf/77.2.001

Sarala, P. \& Eskola, T., 2011. Middle Weichselian Interstadial 
deposit in Petäjäselkä, Northern Finland. E\&GQuaternary Science Journal 60, 488-492.

https://doi.org/10.3285/eg.60.4.07

Sarala, P., Räisänen, J., Johansson, P. \& Eskola, K.O., 2015. Aerial LiDAR analysis in geomorphological mapping and geochronological determination of surficial deposits in the Sodankylä region, northern Finland. GFF 137(4), 293-303.

https://doi.org/10.1080/11035897.2015.1100213

Sarala, P., Väliranta, M., Eskola, T., \& Vaikutiené, G., 2016. First physical evidence for forested environment in the Arctic during MIS 3. Scientific Reports, Vol. 6(29054), 1-9. https://doi.org/10.1038/srep29054

Shaw J., 1979. Genesis of the Sveg tills and Rogen moraines of central Sweden: a model of basal melt out. Boreas 8, 409426. https://doi.org/10.1111/j.1502-3885.1979.tb00437.x

Shaw. J., 1982. Melt-out till in the Edmonton area, Alberta, Canada. Canadian Journal of Earth Sciences, 19, 15481569. https://doi.org/10.1139/e82-134

Siivonen, L., 1975. New results on the history and taxonomy of the mountain, forest and domestic reindeer in Northern Europe. Proceedings of the First International Reindeer and Caribou Symposium, Fairbanks 1972. Biological
Papers of the University of Alaska, Special Report 1, 3341.

Sutinen, R., 1992. Glacial deposits, their electrical properties and surveying by image interpretation and ground penetrating radar. Geological Survey of Finland, Bulletin $359,123 \mathrm{p}$.

Svendsen, J.I., Alexanderson, H., Astakhov, V.I. et al. 2004. Late Quaternary ice sheet history of northern Eurasia. Quaternary Science Reviews 23, 1229-1271. https://doi.org/10.1016/j.quascirev.2003.12.008

Tanner V., 1915. Studier öfver kvartärsystemet i Fennoskandias nordliga delar. III. Om landisens rörelsor och afsmälting i finska Lappland och angränsande trakter. Bulletin de la Commission Geologique de Finlande 38, 815 p.

Tyrväinen, A., 1983. Pre-Quaternary rocks of the Sodankylä and Sattanen map-sheet areas. Geological map of Finland 1:100000 - Explanation to the maps of pre-Quaternary rocks, Sheets 3713 and 3714, 59 p (in Finnish with English summary).

Åberg, A. K., Salonen, V.-P., Korkka-Niemi, K., Rautio, A., Koivisto, E. \& Åberg, S. C. 2017. GIS-based 3D sedimentary model for visualizing complex glacial deposition in Kersilö, Finnish Lapland. Boreal Environment Research 22, 277-298. 